\title{
How raindrops fall
}

\section{雨粒はどうやってできる?}

Fiona Tomkinson

doi:10.1038/news.2009.705/20 July 2009

1 粒の水滴が破裂して、雨となる。

自然の雨のようにさまざまな大きさの小 滴のシャワーが、たった 1 粒の水滴から できることを、フランスの研究者が簡潔 な実験で示した。これまで、地上で見ら れるさまざまな大きさの雨滴は、雨滴どう しが落下中に互いに衝突することによって できると考えられていた。

エクス・マルセイユ大学 (フランス) の 流体力学研究者 Emmanuel Villermaux と大学院生の Benjamin Bossa は、小 さな水滴が蛇口から滴るようすを撮影し、 水滴が落下中にどう変化するのかを観察 した。落下につれ水滴は加速し、空気抵 抗が水滴の凝集力より大きくなると、水 滴は破裂して小滴のシャワーになった。

Villermaux は「こうした実験には通常、 10 メートルの高さが必要です。これは標 準的な実験室で行うには、高すぎます」 と話す。このため、Villermauxらは、水 滴が落ちるときに受ける空気抵抗を増加 させるために、上に向かって流れる空気 噴流を利用し、より短い距離で水滴の落 下を再現した。実験の結果、静止空気中 では 1 粒の水滴は、初めはホットケーキ 型に平たくなり、その後ひっくり返したお わん型に変形し、最後におわんが破裂し て小滴になることがわかった。

Villermauxらは、こうした水滴の形の 変化などの観察をもとに、1 粒の水滴の破 裂を地上での雨滴の大きさの分布と結び つけた。彼らのモデルから、雨滴の大きさ
の分布は、水滴が破裂して小滴になること で十分に説明できることが明らかになった。 この成果は Nature Physicsに発表された

\section{0 年前の実験がヒント}

Villermaux の研究のヒントになったのは、 米国バーモント州の農場経営者Wilson Bentley が 100 年以上前に行った実験 だった2。Bentleyは、雨が降っている屋 外に小麦粉で覆った板を短時間置き、小 麦粉の湿った部分を測定して雨滴の数と 大きさを記録した。

「Bentley の時代、我々がもっているよ うな高速度カメラはありません。しかし、 Bentleyは優れた実験家でした。彼は、 調べるべき問題は雨滴の大きさではなく 雨滴の大きさがばらつく原因だ、と初めて 気づいた人でした」とVillermaux は話す。

雨滴の大きさの分布は、降雨の強さと 密接に関係している。マギル大学 (カナダ、 モントリオール) の Stewart Marshall と Walter Palmer は 60 年以上前に測定を 行い、雨滴の大きさは細かい霧雨よりも 強い嵐の場合に、より大きくばらつくと報 告した ${ }^{3}$ 。今回 Villermaux と Bossa は、 Bentleyが問うた問題に答えるために行っ た実験で、Marshall-Palmer 粒径分布の 再現に成功した。

「答え」は研究者たちが考えていたより も単純だった。小滴の大きさの分布を決め るメカニズムは、1 粒の水滴が空気中を落
下する際の動力学を考慮するだけで説明で きるのだ。 1 粒の水滴が雲から落下し小滴 に分裂するのにかかる時間は、2つの別 の水滴が雲の中で衝突するのにかかるとみ られる時間よりも一般的に短かった。

ブリストル大学（英国）の流体力学の 専門家 Jens Eggers は、「『答え』は、た くさんの経験的な関係式を寄せ集めた もっと複雑なものになるだろう、と私は予 想していました。しかしVillermauxらは、 ちょっとした物理的なアイディアをもとに、 きれいな関係、つまり、単純で普遍的な 関係式で雨滴の平均の大きさと雨の強さ の相関性を説明することができました」と 評価する。

ブルックヘブン国立研究所大気科学部 門（米国、ニューヨーク州アプトン）の Yangang Liu も「この研究は確かに新 鮮でおもしろいですね」と話す。しかし、 「まだ、調べなければならないことがた くさん残っています。例えば、地表で観 測される雨の大部分、つまり地表で観測 される雨滴の大きさ分布の大部分は、雪 片が溶けて生じたものです」と指摘する。 「Villermaux と Bossa の理論は、この 種の降雨でも矛盾しないのでしょうか」と Liuは語っている。(新庄直樹 訳)

1. 1. Villermaux, E. \& Bossa, B. Nature Phys. doi: $10.1038 /$ NPHYS1340 (2009).

2. Bentley, W. Mon. Weath. Rev. 10, 450-456 (1904).

3. Marshall, J. S. \& Palmer, W. M. J. Meteorol. 5, 165-166 (1948).
Q

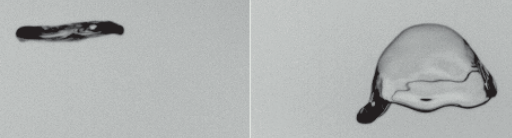

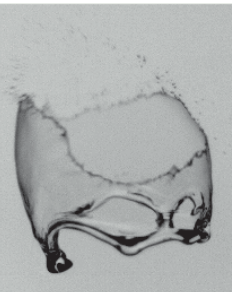

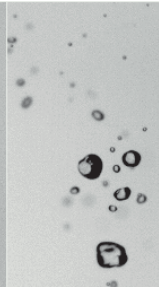

$\rightarrow$

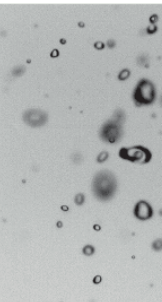

